\title{
Augmentasi tulang alveolar dengan osteogenesis distraksi Alveolar ridge augmentation using distraction osteogenesis
}

\author{
${ }^{1}$ Siti Sarah Aulia Amrullah, ${ }^{1}$ Rosida Sani, ${ }^{1}$ Nurfadhilah Arifin, ${ }^{2}$ Muhammad Ruslin \\ ${ }^{1}$ Mahasiswa Tahapan Profesi \\ ${ }^{2}$ Bagian Ilmu Bedah Mulut \\ Fakultas Kedokteran Gigi Universitas Hasanuddin \\ Makassar, Indonesia
}

\begin{abstract}
Augmentation of the alveolar ridge is widely performed in implant treatment to create predictable function and esthetics in area with inadequate bone volume. There are some different ways to augment the alveolar ridge. Distraction osteogenesis is a new method in increasing the width of the ridge and preparing a sufficient bed for implant or prosthesis. Distraction osteogenesis result in formation of new bone between bone segments that are separated gradually by incremental traction. Alveolar widening by distraction osteogenesis is an alternative method for reconstructing alveolar atrophy that is similar to alveolar split grafting but without grafting, which offers many advantages over traditional techniques. This paper is aimed to discuss considerations and technique of alveolar ridge augmentation for preparing adequate bone volume before applying implant by using distraction osteogenesis technique.
\end{abstract}

Keywords : alveolar ridge augmentation, distraction osteogenesis, implant

\begin{abstract}
ABSTRAK
Penambahan tulang alveolar pada perawatan implan, merupakan hal yang umum dilakukan untuk memperoleh fungsi serta estetik yang diharapkan pada daerah tulang yang tidak adekuat. Terdapat beberapa cara untuk menambah volume tulang alveolar. Osteogenesis distraksi merupakan salah satu metode terbaru dalam menambah ketebalan tulang alveolar dan mempersiapkan dasar untuk penempatan implan ataupun prostesis. Osteogenesis distraksi membentuk tulang baru diantara segmen tulang yang terpisah secara bertahap setiap penambahan gaya tarik alat pada daerah tersebut. Pelebaran tulang alveolar dengan cara osteogenesis distraksi merupakan salah satu metode alternatif yang memberikan berbagai keuntungan dibandingkan teknik konvensional dalam hal merekonstruksi tulang alveolar yang telah mengalami atrofi. Cara ini menyerupai metode pencangkokan tulang, hanya saja tanpa pencangkokan. Penulisan makalah ini dimaksudkan untuk mendiskusikan beberapa pertimbangan dan teknik penambahan tulang alveolar untuk mempersiapkan volume tulang yang adekuat sebelum pemasangan implan, dengan metode distraction osteogenesis.

Kata kunci: penambahan tulang alveolar, osteogeness distraksi, implan
\end{abstract}

Koresponden: Siti Sarah Aulia Amrullah, Fakultas Kedokteran Gigi Universitas Hasanuddin, Jl. Kandea No.5, Makassar, Indonesia. E-mail: sarah_fkg@yahoo.com

\section{PENDAHULUAN}

Resorpsi tulang alveolar merupakan proses biofisika yang umum terjadi setelah kehilangan gigi alami. Atrofi tulang alveolar merupakan gangguan yang menyebabkan beberapa masalah fisik pada pasien edentulus. Pasien yang mengalami edentulus sebagian atau totalis membutuhkan penggantian giginya yang hilang. Hal ini dapat diatasi dengan gigitiruan lepasan, gigitiruan cekat, atau gigitiruan dukungan implan. ${ }^{1}$

Penggunaan implan sebagai salah satu upaya rehabilitasi pada pasien yang kehilangan gigi baik sebagian maupun seluruhnya menjadi populer pada akhir dekade ini, dengan hasil jangka panjang yang dapat diandalkan. Salah satu masalah yang paling umum dan mendasar dalam perawatan implan gigi adalah kebutuhan akan tinggi atau tebal tulang yang sering yang kurang memadai, baik pada mandibula maupun maksila. ${ }^{2}$
Kerusakan alveolar dapat terjadi akibat faktor bawaan atau hal diperoleh. Kerusakan alveolar akibat faktor hal diperoleh diklasifikasikan menjadi kerusakan vertikal dan horisontal, dapat disebabkan oleh proses pencabutan, penyakit periodontal, gigi trauma avulsi, atau resesi yang terjadi akibat tumor. Atrofi tulang alveolar menghambat penempatan implan secara ideal yang membutuhkan estetik dan fungsi yang baik, terlebih lagi ketika tinggi tulang alveolar tidak memadai sehingga menghambat penggunaan implan karena rasio mahkota-implan yang tidak adekuat. ${ }^{2}$

Beberapa teknik pembedahan diajukan untuk memperbaiki keadaan tulang yang tidak adekuat, diantaranya autogenus bone graft $(A B G)$, verticalguided bone regeneration (GBR), dan osteogensis distraksi (OD). Bone graft dikenal sebagai upaya untuk menanggulangi resorpsi tulang alveolar yang berlebihan dengan teknik pencangkokan tulang 
sehingga diharapkan dapat mengembalikan tulang alveolar pada kondisi yang ideal untuk penempatan implan. Selain itu, GBR merupakan teknik bedah untuk meningkatkan formasi sel-sel tulang baru dalam upaya penambahan tulang alveolar. Teknik tersebut membutuhkan keterampilan yang cukup tinggi sebab teknik ini sangat sensitif. Adapun OD merupakan metode untuk mempersiapkan volume tulang yang memadai untuk implan dengan cara memotong tulang pada regio yang akan ditinggikan lalu segmen tulang yang terpisah dipasangi alat distraksi, dan diberi gaya secara bertahap. ${ }^{3-6}$

Penulisan makalah ini dimaksudkan untuk mendiskusikan beberapa pertimbangan dan teknik penambahan tulang alveolar untuk mempersiapkan volume tulang yang adekuat sebelum pemasangan implan, dengan metode distraction osteogenesis.

\section{TINJAUAN PUSTAKA}

Osteogenesis distraksi alveolar (ODA) adalah teknik pelebaran sisa tulang alveolar yang tersedia, yang mengikuti mekanisme penyembuhan tubuh secara alami, dengan menghasilkan tulang baru untuk penambahan tinggi tulang alveolar. Teknik ini memiliki kemampuan secara simultan untuk meningkatkan volume tulang dan jaringan lunak yang mengalami defisiensi, menawarkan hasil yang dapat diprediksi dengan tingkat keabnormalan yang cukup rendah,serta infeksi dan waktu penyembuhan yang relatif singkat terhadap kemajuan rehabilitasi implan (12 minggu) bila dibandingkan dengan metode lain. $^{7}$

Tujuan utama ODA yaitu untuk menciptakan tulang yang baru dan volume jaringan lunak yang adekuat sehingga menjamin tinggi dan tebal tulang alveolar yang memadai untuk penempatan implan yang akurat. Selanjutnya OD diaplikasikan ke alat ekspansi vertikal pada tulang alveolar yang telah melalui proses eksperimen dan hasil klinis yang baik. $^{2}$

Tindakan OD memicu pembentukan tulang baru diantara tulang yang terpisah secara bertahap dengan peningkatan tarikan alat yang digunakan. Tegangan pada callus dan jaringan lunak sekitar menghasilkan ekspansi pada keduanya sehingga callus terganti oleh tulang. Osteogenesis distraksi dilakukan dengan alat intra- ataupun extraosseus. ${ }^{6}$ Teknik ini relatif tidak rumit dan menghindari kebutuhan pencangkokan tulang. Osteogenesis distrasi meliputi tahap osteotomi atau pemotongan sambungan segmen tulang, periode laten untuk memberikan kesempatan terhadap proses inflamasi, dan penyembuhan awal, distraksi atau periode manipulasi callus, dan periode penyatuan tulang. ${ }^{8}$
Teknik distraksi maksilofasial telah menuntun keberhasilan peninggian mandibula dan maksila. Prosedur ini membantu pasien khususnya pada pasien dengan sindrom kraniofasial, celah maksila, atau tumor pada bagian maksilofasial. Teknik ODA merupakan cara terbaru dan kesuksesannya telah terdokumentasi secara luas, serta perkembangan alat distraksi berukuran kecil telah membuat OD dapat dilakukan pada bagian tulang yang kecil. ${ }^{8}$

Indikasi ODA dapat berupa kelainan tulang alveolar secara bawaan atau kehilangan tulang alveolar yang didapat. Kehilangan tulang alveolar yang didapat, disebabkan karena kelainan setelah pencabutan gigi, trauma akibat avulsi, penyakit periodontal, dan/atau pemakaian gigitiruan dalam jangka waktu yang lama yang mengakibatkan atrofi. Pada banyak kasus, kehilangan tulang secara signifikan terjadi pada bidang horisontal. ${ }^{9}$

Kesuksesan OD menganut beberapa prinsip, diantaranya pemeliharaan jaringan osteogenik, menjaga kestabilan plat fiksasi pada distraktor, mengamati periode laten, kesesuaian kecepatan dan ritme pada proses distraksi, dan periode penyatuan tulang. ${ }^{10}$

Pemeliharaan jaringan osteogenik merupakan hal yang penting pada saat osteotomi. Kelangsungan hidup segmen yang terpisah sangat menentukan kesuksesan OD karena sistem vaskular pada sumsum-tulang belakang terganggu oleh prosedur osteotomi. Salah satu sumber suplai darah terbesar untuk tulang adalah periosteum. Oleh karena itu, prosedur yang minimal kerusakan periosteumnya patut diperhatikan. Hal ini sebaiknya diselesaikan dengan cara insisi vestibular. Insisi vestibular menyebabkan luka yang besar pada perlekatan jaringan pada wajah dan puncak tulang, terlebih lagi jaringan di daerah lingual atau palatal yang utuh. Pemeliharaan jaringan pada zona tersebut harus didukung oleh jumlah periosteum yang memadai.Sebaliknya,insisi crestal yang merupakan pilihan insisi yang paling sering digunakan dalam prosedur implan, sebaiknya dihindari karena dapat menyebabkan kehilangan suplai darah ke bagian puncak segmen yang termobilisasi. Perawatan sempurna harus dapat dilakukan selama osteotomi untuk melindungi daerah perlekatan dan menjaga kebersihan flap mukoperiosteal di daerah lingual sebab daerah tersebut menjadi sumber vaskularisasi utama untuk segmen yang termobilisasi.

Kestabilan alat distraksi juga merupakan hal yang penting. Gaya pembengkokan dan pemotongan menyebabkan fraktur mikrokolom dan pendarahan lokal, sehingga diproduksi fibrokartilago, akhirnya segmen tulang yang telah termobilisasi terpisah. 
Kegagalan alat distraksi menyebabkan kegagalan segmen, infeksi, atau minimal relapse pada tulang yang didistraksi. Ilizarov merekomendasikan cincin distraktor sepanjang tulang untuk mengikuti fiksasi sirkumferensial selama distraksi. Hal ini tidak memungkinkan meskipun dalam aplikasi alveolar. Alat yang dapat dilekatkan pada kedua segmen yang dimobilisasi dan tulang basal lebih menjamin kestabilan.

Periode laten merupakan waktu antara prosedur osteotomi dengan perlekatan alat distraksi dan dimulainya proses distraksi. Periode laten diikuti pembentukan jembatan fibrovaskular antara segmen tulang yang dimobilisasi dan host.Berbagai pustaka menjelaskan mengenai perbedaan waktu yang pasti untuk memulai distraksi, meskipun periode laten yang adekuat berkisar dari hari ke-5 sampai ke-10.Aktivasi awal mungkin menyebabkan luka vertikal pada tepi alveolar. Periode laten yang diperpanjang lebih dari 3 minggu harus dihindari karena dapat membentuk osifikasi segmen tulang dan mencegah perpindahan tulang.

Kecepatan distraksi menunjukkan jarak segmen tulang yang berpindah. Penelitian mengindikasikan 0,5-1 $\mathrm{mm}$ per hari untuk tulang panjang dan tulang maksilofasial. Kecepatan distraksi dibawah $0,5 \mathrm{~mm}$ per hari dapat menyebabkan osifikasi dini pada segmen di sekitar tulang, sedangkan kecepatan yang melebihi $1 \mathrm{~mm}$ per hari akan menghasilkan kekuatan yang berlebihan yang bertanggung jawab terhadap resorpsi tulang. Kelebihan kekuatan ini dapat menyebabkan iskemia lokal dalam zona regenerasi yang menyebabkan penundaaan osifikasi atau tidak akan bersatunya segmen tulang. Ritme distraksi juga memainkan peranan penting dalam kesuksesan prosedur. Hal ini diasumsikan bahwa kecepatan distraksi yang kontinyu adalah ideal. Pada aplikasi klinik, hal ini tidak dipraktekkan dan disarankan prosedur distraksi dari satu manipulasi menjadi 2, 3, hingga 4 per harinya.

Periode penyatuan tulang merupakan waktu setelah distraksi yang diinginkan telah dicapai. Selama fase ini, tidak ada kekuatan yang diberikan di atas tulang. Alat distraksi tetap diletakkan pada daerah tersebut untuk memastikan kestabilan pada saat tulang callus baru yang termobilisasi telah matang dan mengalami remodeling. Setelah periode ini, distraktor dapat dilepas dan dilakukan penempatan implan. Ilizarov merekomendasi periode penyatuan tulang sekurang-kurangnya sama dengan waktu distraksi. Beberapa literatur mengungkapkan bahwa waktu yang dibutuhkan untuk periode penyatuan tulang paling cepat 3 minggu dan paling lama 3 bulan, untuk mencegah segmen tulang mengalami relapse.

Prosedur bedah OD terbagi atas osteogensis distraksi horisontal dan osteogenesis distraksi vertikal.Horizontal distraction osteogenesis diawali dengan anastesi lokal, insisi pada tulang crestal mucoperosteal dilakukan kemudian dilebarkan ke arah anterior dan posterior (Gambar 1A). Flap dibuat tidak terlalu tampak, sehingga tulang crestal terbuka minimal dan dengan menggunakan round bur kecil dibuat pada pertengahan tulang crestal. Pemotongan tulang sedalam $\pm 10 \mathrm{~mm}$ dilakukan dengan menggunakan reciprocating saw atau pisau piezoelectric. Pemotongan tulang dibuat pada daerah insisi vertikal anterior dan posterior dengan menggunakan microsagital saw yang tampak pada gambar 1B. Pisau osteotome yang tipis digunakan untuk mengeluarkan patahan tulang bukal dan luka ditutup (Gambar 2A). Satu minggu kemudian laster crest widener diletakkan secara perkutan (Gambar 2B). Sebuah titanium yang aman dipasang pada lubang di daerah lengan alat, paling baik dilakukan sebelum masuknya alat (Gambar 3A). ${ }^{9}$
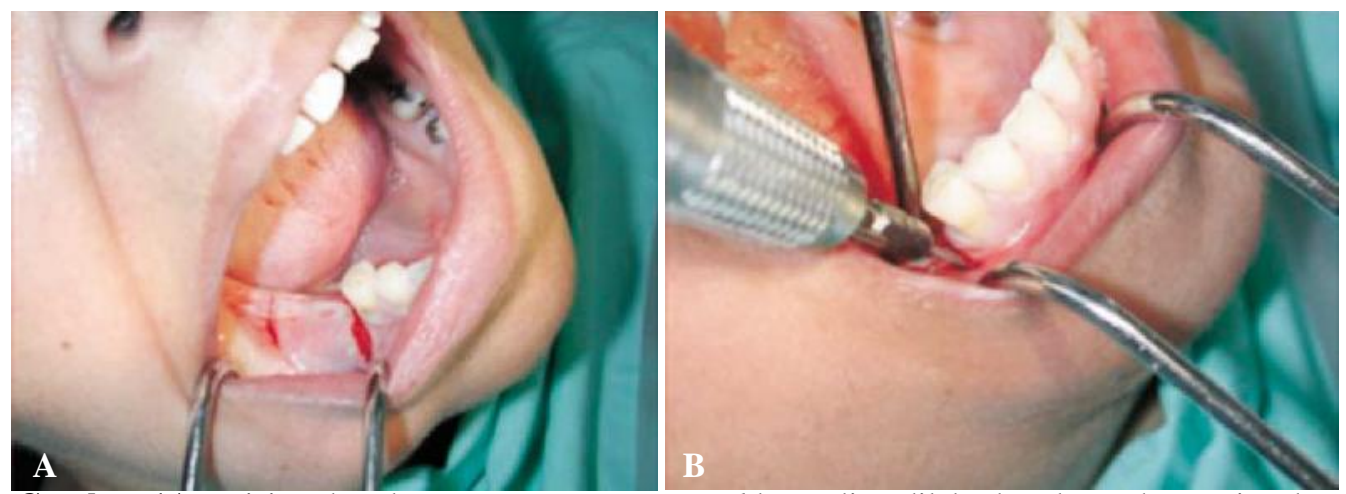

Gambar 1A Insisi pada tulang crest mucoperiosteal kemudian dilebarkan ke arah anterior dan posterior, B pemotongan tulang pada daerah insisi vertikal anterior dan posterior menggunakan reciprocating saw, pisau piezoelectric dan sagital microsaw (Sumber: Laster Z, Rachmiel A, Jensen OT. Alveolar width distraction osteogenesis for early implant placement. J Oral Maxillofac Surg 2005; 63:1724-9). ${ }^{9}$ 
Dua gerakan rotasi yang berlawanan arah jarum jam dilakukan pada sekrup yang akan diaktivasi untuk menarik alat dalam tulang dan memperkuat pergerakannya. Aktivasi piranti yang dilakukan, direkomendasikan rata-rata $0,4 \mathrm{~mm}$ per hari $(1 / 2$ putaran dua kali sehari) pasien harus diperiksa oleh ahli bedah setiap 4 hari (Gambar 3B). Setelah lebar celah yang cukup diperoleh (10-14 hari) aktivasi dihentikan (overdistraction 1-2 mm dianjurkan) laster crest widener disimpan selama 7-10 hari untuk penyatuan.Alat tersebut kemudian dilepaskan di bawah kontrol anastesi lokal tanpa penutupan jaringan lunak (Gambar 4A). Penempatan implan secara transgingiva dilakukan segera setelah 7-10 hari setelah pengangkatan alat distraktor meskipun mineralisasi belum sempurna (Gambar 4B). ${ }^{9}$

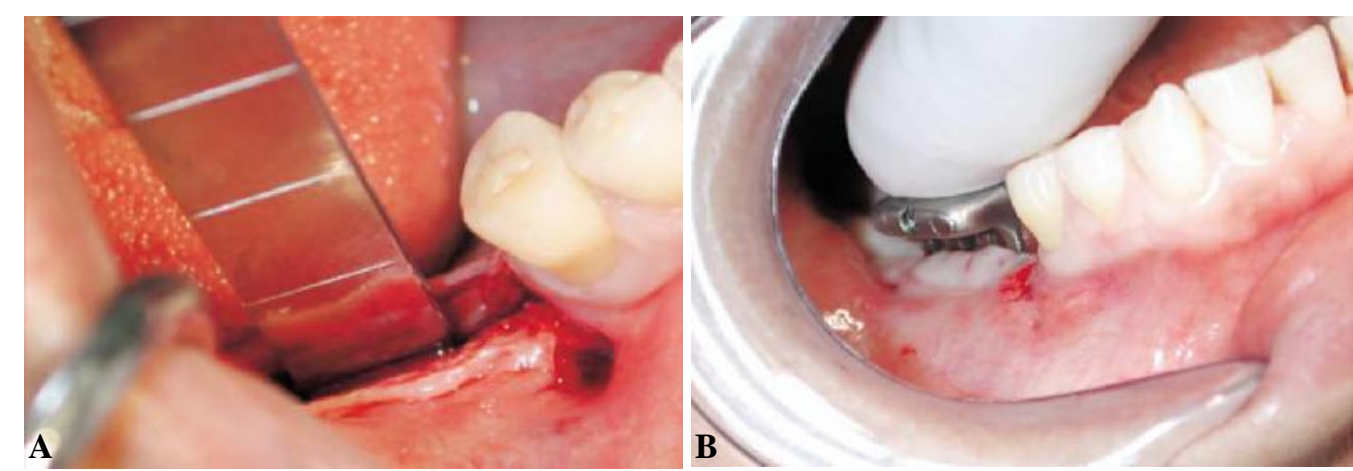

Gambar 2A Sebuah pisau osteotome tipis digunakan untuk mengeluarkan patahan tulang bukal, B satu minggu kemudian, laster crest widener diletakkan perkutan (Sumber: Laster Z, Rachmiel A, Jensen OT. Alveolar width distraction osteogenesis for early implant placement. J Oral Maxillofac Surg 2005; 63:1724-9). ${ }^{9}$
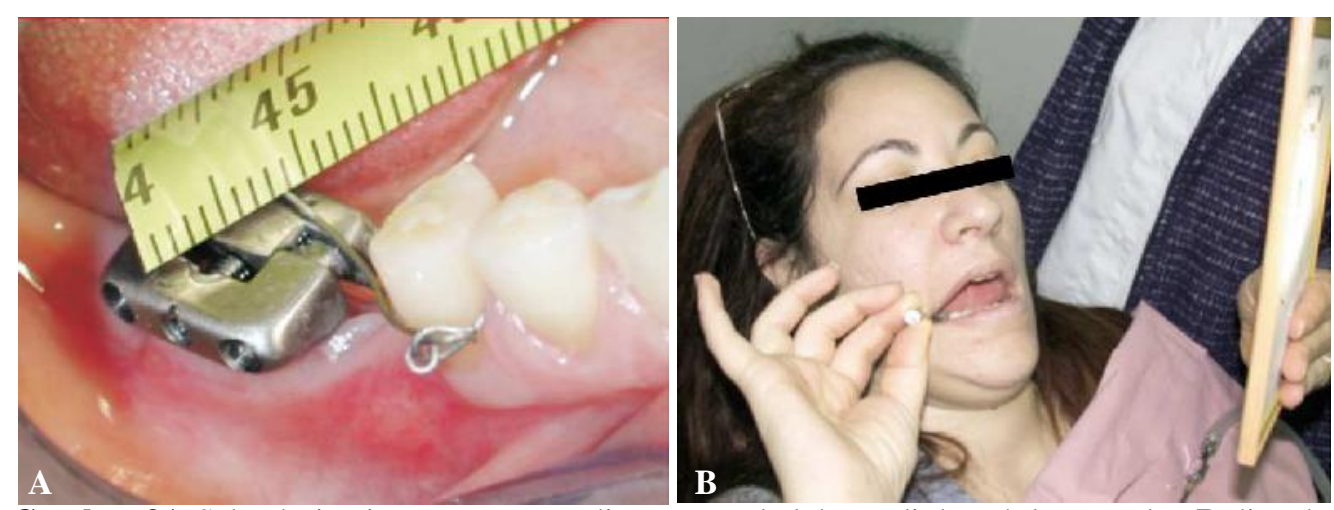

Gambar 3A Sebuah titanium yang aman dipasang pada lubang di daerah lengan alat, B distraksi dimulai setelah 1 minggu, 21/2 putaran per hari $(0,4 \mathrm{~mm})$, dilakukan oleh pasien sendiri di rumah (Sumber: Laster Z, Rachmiel A, Jensen OT. Alveolar width distraction osteogenesis for early implant placement. J Oral Maxillofac Surg 2005; 63:1724-9). ${ }^{9}$
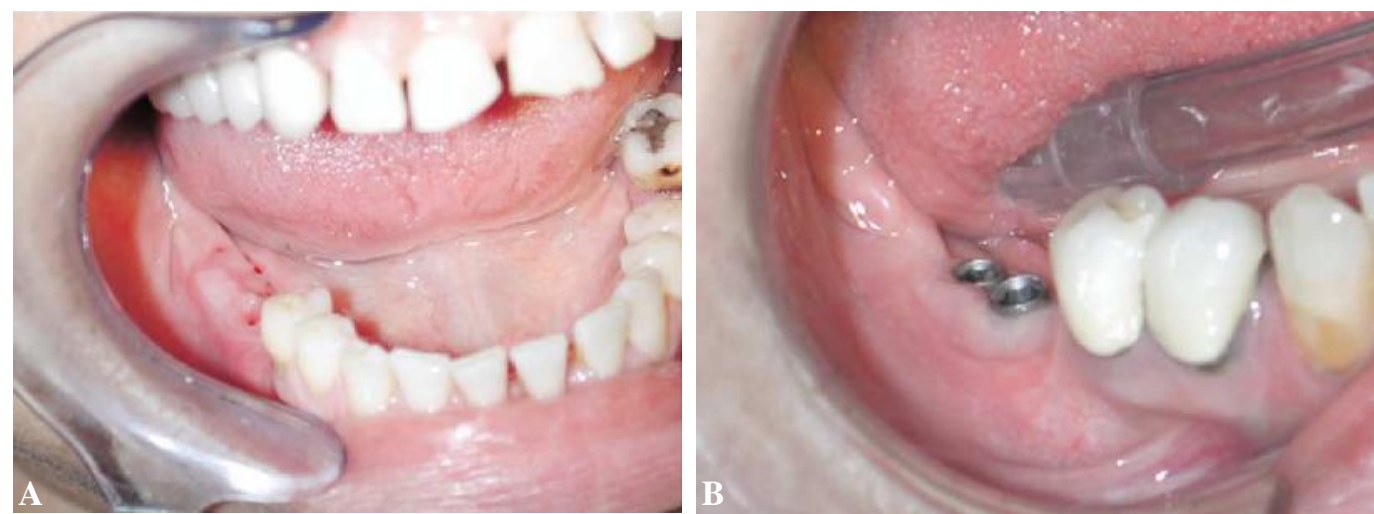

Gambar 4A Saat ketinggian tulang yang diharapkan sudah cukup, aktivasi dihentikan. Alat dilepas 7-10 hari setelah periode penyatuan tulang, dengan anestesi lokal, B pemasangan implan dilakukan setelah 7-10 hari alat dilepas. 
Tabel 1 Komplikasi, dampak, dan perawatan distraksi alveolar ${ }^{11}$

\begin{tabular}{|c|c|c|}
\hline Komplikasi & Perawatan & Dampak \\
\hline \multicolumn{3}{|l|}{ Intraoperatif } \\
\hline Fraktur dari bagian yang bergerak & Pencegahan dengan pengukuran yang tepat & $\begin{array}{l}\text { Pembentukan tulang yang } \\
\text { tidak tepat }\end{array}$ \\
\hline $\begin{array}{l}\text { Kesulitan menyelesaikan osteotomi } \\
\text { pada daerah lingual }\end{array}$ & Menggunakan alat yang tepat & $\begin{array}{l}\text { Memperpanjang waktu } \\
\text { operasi }\end{array}$ \\
\hline Pemanjangan threaded rod berlebih & Memotong rod & $\begin{array}{l}\text { Jika tidak terkoreksi, } \\
\text { mengganggu oklusi }\end{array}$ \\
\hline \multicolumn{3}{|l|}{ Selama distraksi } \\
\hline Arah distraksi yang tidak tepat & $\begin{array}{l}\text { Memperhatikan sudut yang tepat dari } \\
\text { penempatan distraktor } \\
\text { Peletakan dengan memperhatikan efek } \\
\text { terhadap mukoperiosteum pada area lingual } \\
\text { Menggunakan alat ortodontik }\end{array}$ & $\begin{array}{l}\text { Pembentukan tulang pada } \\
\text { arah yang salah. }\end{array}$ \\
\hline $\begin{array}{l}\text { Perforasi mukosa karena bagian yang } \\
\text { bergerak } \\
\text { Kerusakan atau distraktor hilang }\end{array}$ & $\begin{array}{l}\text { Menghaluskan bagian yang sangat keras } \\
\text { dengan bur atau rongeur. }\end{array}$ & Ulkus pada daerah lingual \\
\hline Jahitan bedah yang terbuka & $\begin{array}{l}\text { Umumnya tidak dibutuhkan perawatan } \\
\text { khusus; dilakukan penutupan kedua }\end{array}$ & $\begin{array}{l}\text { Sequelae yang tidak } \\
\text { terobservasi }\end{array}$ \\
\hline \multicolumn{3}{|l|}{ Pasca distraksi } \\
\hline Kelainan pembentukan tulang & $\begin{array}{l}\text { Regenerasi tulang yang terarah } \\
\text { Aplikasi lapisan titanium selama osteotomi }\end{array}$ & Gap pada sekitar implan \\
\hline \multicolumn{3}{|l|}{ Komplikasi lain } \\
\hline Dysesthesia nervus mentalis & & \\
\hline
\end{tabular}

Teknik vertical distraction osteogenesis diawali pemberian anastesi lokal, insisi dilakukan sepanjang tulang alveolar, lalu flap vestibular mисореriosteal diangkat, pertahankan perlekatan mисореriosteum pada daerah lingual hingga daerah yang bergerak. Segmen yang bergerak dipotong hingga berbentuk trapesium terbalik, sehingga tidak mengganggu pergerakan selama prosedur distraksi. Osteotomi dilakukan dengan rotary instrument (sisi pemotong bur, discs, dan reciprocating saw) serta chisel. Segmen yang berpindah digerakkan secara keseluruhan meskipun tersisa perlekatan pada mucoperiousteum pada daerah lingual. ${ }^{11}$

Saat distraktor telah diletakkan, tanpa menjahit flap mucoperiosteal, pada saat pembedahan yang sama, bagian yang bergerak tersebut dengan segera dibuka hingga ketinggian $5 \mathrm{~mm}$ untuk menguatkan pergerakan yang adekuat dan arah pergerakan yang tepat dan tidak terdapat intervensi antara bagian yang bergerak dengan tulang basal. Segmen yang bergerak kemudian dikembalikan pada posisi awal.

Distraksi dimulai 7 hari kemudian dengan 0,5 $\mathrm{mm}$ tiap hari setiap 12 jam selama 5 hari. Setelah 12 minggu, distraktor dilepas dan implan dipasang. Pada minggu ke 14 setelah implan diletakkan, restorasi prostetik mulai dilakukan.

\section{PEMBAHASAN}

Teknik ODA merupakan perawatan alternatif yang membutuhkan waktu penanganan yang lebih singkat dibandingkan dengan teknik regenerasi lain karena segmen yang didistraksi terbentuk dengan baik hanya dalam waktu 12 minggu. Tingkat keparahan nyeri merupakan salah satu indikator utama untuk mengukur tingkat ketidaknyamanan pasien selama dan setelah operasi. ${ }^{7}$

Kekuatan, dalam hal ini kuantitas, kualitas, dan distribusi jaringan tulang terhubung langsung dengan beban yang diterima. Berdasarkan jumlah energi yang diterimanya, maka tulang yang tidak memperoleh beban secara adekuat akan mengalami resorpsi dan sistem skeletal secara berkala akan beradaptasi untuk mencapai kekuatan optimal dengan massa yang minimal. ${ }^{12}$

Perawatan dengan ODA menawarkan lebih banyak keuntungan dibanding teknik bone graft. Keuntungan OD antara lain hanya sedikit atau tidak terdapat resorpsi tulang seperti yang biasa terjadi pada rekonstruksi bone graft,memungkinkan terjadi proliferasi attached gingiva,dan untuk menghindari penambahan jaringan lunak. Oleh karena itu, OD mencegah morbiditas daerah donor yang terkait berhubungan dengan jaringan keras dan lunak. Keuntungan lain OD, yaitu waktu penempatan implan. Proses regenerasi mineral yang cepat oleh penebalan tulang trabekula, sehingga implan diletakkan dalam jangka waktu yang relatif singkat (4 sampai 8 minggu pasca operasi) dan proses penyembuhannya membutuhkan waktu sekitar setengah dari waktu teknik block graft. $^{8,9}$ 
Selain beberapa keuntungan yang telah disebutkan di atas, terdapat beberapa kerugian dari teknik tersebut, yaitu kemungkinan terjadinya infeksi selama periode perawatan serta beberapa komplikasi. Komplikasi tersebut diantaranya, kemungkinan terjadinya fraktur pada segmen yang bergerak, kesulitan dalam penyelesaian osteotomi pada daerah lingual, alat dengan ukuran panjang yang berlebih, arah distraksi yang tidak tepat, perforasi jaringan mukosa akibat segmen yang bergerak, penjahitan kembali luka operasi yang terbuka, serta gangguan pembentukan tulang. Gracia dkk melaporkan bahwa sebagian besar komplikasi dapat dianggap tidak terlalu berbahaya dan mudah untuk dihindari atau diselesaikan selama operator melakukan prosedur yang sesuai. ${ }^{13}$

Dari pembahasan sebelumnya, disimpulkan prosedur penambahan tulang alveolar semakin luas penerapannya dalam perawatan implan. Teknik OD merupakan salah satu prosedur bedah dalam mengoreksi atrofi tulang alveolar yang berlebihan, selain teknik bone graft dan GBR. Penambahan tulang alveolar ditujukan untuk menghasilkan fungsi dan estetik yang diharapkan pada kasus dengan kuantitas tulang yang kurang memadai. Prinsip OD yang perlu diperhatikan demi mencapai perawatan yang berhasil diantaranya pemeliharaan jaringan osteogenik, mempertahankan kestabilan plat fiksasi pada distraktor, mengamati periode laten, kesesuaian kecepatan dan ritme pada proses distraksi, dan periode penyatuan tulang.

Kehadiran metode baru ini diharapkan dapat memberikan alternatif baru bagi para ahli bedah mulut yang akan merencanakan rekonstruksi dan rehabilitasi pasien penderita edentulus yang ingin mendapatkan perawatan implan dan juga prostetik lainnya. Seiring keuntungan yang ditawarkan, metode ini juga masih mempunyai beberapa kekurangan yang diharapkan dapat diminimalisasi kejadiannya.

\section{DAFTAR PUSTAKA}

1. Rahmani ME, Sargozaee N, Sedighi MR. A pilot study of ridge augmentation using the osteodistraction technique and interpositional bone graft method in sheep. J Mashhad Dent School 2007; 31:12.

2. Matoulas E, Nazaroglou I, Kafas P, Charitoudi D. The reconstructive potential of distraction osteogenesis on defect of the alveolar ridge before dental implants placement: A review. J Med Sci 2009; 3(3): 123-6.

3. Proussaefs P. Inferior alveolar nerve transposing in a situation with minimal bone height: A clinical report. J Oral Implant 2005; 31 (4): 180.

4. Chiapasco M, Zaniboni M, Rimondini L. Autogenous onlay bone grafts vs alveolar distraction osteogenesis for the correction of vertically deficient edentulous ridge: A ridge. Clinic Oral Impl Res 2007; 18:432.

5. Al-Ghamdi HS, Mokeem SA, Anil S. Current concepts in alveolar bone augmentation: A critical appraisal. Saudi Dent J 2007; 19(2): 74.

6. Enislidis G, Fock N, Ewers R. Distraction osteogenesis with subperiosteal devices in edentulous mandible. J Oral Maxillofac Surg 2005; 43:399.

7. Allais M, Maurette PE, Mazzonetto R, Filho JRL. Patient's perception of the events during and after osteogenic alveolar distraction. Med Oral Path Oral Buccal 2007; 12: 226.

8. Walker DA. Mandibular distraction osteogenesis for endosseous dental implants. J de I'Assoc Dent Canadienne 2005; 71(3): 171-3.

9. Laster Z, Rachmiel A, Jensen OT. Alveolar width distraction osteogenesis for early implant placement. J Oral Maxillofac Surg 2005; 63:1724-9.

10. Ley J, Cranin AN. Distraction osteogenesis for augmenting the deficient alveolar ridge in preparation for dental implant placement: A case report. J Oral Implant 2004; 30 (1): 14, 16, 18, 20.

11. Garcia AG, Martin MS, Vila PG, Marceiras L. Minor complications arising in alveolar distraction osteogenesis. J Oral Maxillofac Surg 2002; 60: 497-9.

12. Naert I, van Steenberghe D, Worthington P. Osseointegration in oral rehabilitation: An introductory textbook. London: Quintessence Publishing Co., Ltd; 1993. p.157.

13. Fukuda M, Lino M, Ohnuki T, Nagai H, Takahashi T. Vertical alveolar distraction osteogenesis with complications in a reconstructed mandible. J Oral Implant 2003; 29 (4): 185, 188. 